\title{
CHOLERA AND SOCIETY: ANTI-EPIDEMIC PRACTICES IN WESTERN EUROPE, THE RUSSIAN AND OTTOMAN EMPIRES IN THE 19TH - EARLY 20TH CENTURIES
}

Grigory AFANASIEVa

\begin{abstract}
The article is devoted to a comparative analysis of the composition and dynamics of the development of the anti-epidemic response of state, scientific, medical and public institutions of the leading countries of Western Europe, the Russian and Ottoman empires during the five cholera pandemic waves in the 19th - early 20th centuries. The difference in the unique features of social, cultural, political life and, at the same time, a general orientation towards one vector of development (western trend) make the analysis possible and relevant. The actuality layed not only in the general scientific sense, but also applicable to the current antiepidemic practice of the emerging covid-19 pandemic. The comparative study is based on a comprehensive analysis of Russian, American, English and Turkish historiography. The work proves that the development of an anti-epidemic strategy is always the product of the already established tendencies of perception and response to emergencies and extraordinary situations in society, formats or patterns of "responses" to a global "challenge", which in the course of events are only subject to certain adjustments, additions, updates. Confidence in the chosen strategy or the search for a strategy, the harmony of the chosen path or its search for social trends, plays a huge role. So, the general situation in Western European countries with a set of social characteristics inherent in them by the beginning of the 19th century (secularism, the leading role science and its self-developing potential, the development of public life and civil society institutions) only reinforced the chosen direction of the search for anti-epidemic policy algorithms, despite the delayed result, led to positive shifts both in the fight against cholera and the development of medicine in society as a whole (health care system, social hygiene, sanitation, preventive vaccination, etc.). Irregularities in the development of these social signs, with a general orientation towards a search path similar to Western Europe, the inconsistency of the relationship between power, medicine and society in the Russian Empire, did not lead, despite noticeable successes in certain clusters, to the organization of a common national health system till the beginning of the XX century subject to the vast territorial extent of the country, the key to effective implementation of choleratic measures. The transition to the European principles of anti-epidemic response in the harsh conditions of constant foreign policy pressure, the almost complete absence of a social foundation for the accumulation of innovations, or its deliberately secondary nature for social dispositions, the unpreparedness of the social system to massively rigid introduction of new principles, institutions, methods, practices and rules in society, as happened with the Ottoman Empire in the 19th century, did not contribute, despite the creation of almost all links and the maintenance of their performance, the addition of a national health system capable of
\end{abstract}

a Asst. Prof. Dr., Gatchina Palace and Estate Museum, greenia2006@rambler.ru 
developing an effective anti-epidemic response system in the conditions of the Ottoman society.

Keywords: History of Russia, pandemic, cholera, anti-epidemic response, quarantine, health care, hygiene, sanitation.

$$
\text { 旅淡 }
$$

\section{KOLERA VE TOPLUM: 19 VE 20. YÜZYIL BAȘLARINDA BATI AVRUPA, RUSYA VE OSMANLI IMMPARATORLUKLARININ SALGINLARA KARȘI UYGULAMALARI}

Öz

Makale 19. yüzyıl ve 20. yüzyılın başlarında Batı Avrupa'nın büyük ülkelerinin ve aynı zamanda Rus ve Osmanlı imparatorluklarının yerleşim bölgelerinde etkisini gösteren 5 kolera salgını boyunca devlet kurumlarının, bilimsel-tıbbi merkezlerin ve kamu kuruluşlarının salgınla mücadeledeki gelişim dinamiklerini ve yapılarının karşılaştırmalı analizini konu edinmektedir. Sosyal, kültürel, politik yaşamın kendine has özelliklerindeki farklılık ve bununla birlikte tek bir gelişme vektörüne doğru genel yönlendirme, sadece genel bilimsel manada analizi mümkün ve güncel hale getirmez; ayı zamanda hâlihazırdaki korona salgınına (covid-19) karşı ortaya konan mücadelede de uygulanabilir. Bu karşılaştırmalı inceleme; Rus, Amerikan, İngiliz ve Türk tarih yazımının bütüncül bir analizi ile inşa edilmiştir. Çalışmada, bir salgına karşı strateji geliştirilmenin her zaman toplumda var olan kabul eğilimlerinde ve acil durumlara tepkide ve olağanüstü durumlarda; küresel "meydan okumalara" karşı verilen "cevapların" formatları veya biçimlerinde olayların gelişimi sırasında sadece belirli ayarlamalar, eklemeler, güncellemeler, özel yenilikler ve uygulamaların sonuç verdiği ortaya konulmaktadır. Belirlenen stratejiye duyulan güven veya bu stratejinin arayışı, seçilen yolun uyumu veya sosyal eğilimler için aranması bu hususta büyük rol oynar. Şöyle ki, doğası gereği Batı Avrupa ülkelerindeki genel durumun, 19. yüzyılın başlarına kadarki bir dizi toplumsal belirtisi (sekülerizm, bilimin lider rolü ve onun kendi kendine gelişme potansiyeli, sivil toplum kuruluşlarının ve toplum yaşamının gelişmişliği) yalnızca salgın karşıtı politika algoritmaları arayışının seçilen yönlerini güçlendirdi. Yavaş elde edilen sonuçlara rağmen bu hem kolera ile mücadelede hem de bir bütün olarak toplumda tıbbın gelişiminde olumlu değişimlere yol açtı (sağlık sistemi, sosyal hijyen, sanitasyon, önleyici aşılama vd.). Rus İmparatorluğu'nda ise batı Avrupa'nın arayış yoluna benzer genel eğilimler sırasında bu toplumsal yapıların gelişimindeki düzensizlik iktidar, tıp ve toplum ilişkilerindeki tutarsızlık 20. yüzyılın başına kadar devam etti. Ulusal sağlık sisteminin genel organizasyonu çerçevesinde belirli alanlardaki önemli başarılara rağmen ülkenin coğrafi koşulları da koleraya karşı önlemlerin etkili bir şekilde uygulanmasına mani olmuştur. Sistemin tüm halkalarının oluşturulmasına ve etkinliğinin korunmasına rağmen, 19. Yüzyıl Osmanlı toplumu koşullarında salgına karşı etkili bir müdahale sistemi geliştirebilecek ulusal sağlık sisteminin oluşmasını engelleyen birçok etken mevcut idi. Bunları şu şekilde sıralamak mümkündür: Osmanlıya karşı zorlu koşullardaki dış politika baskısının Avrupa'nın salgın karşıtı uygulamalarına geçişi Osmanlıda engellemesi; yeniliklerin harekete geçirilebilmesi için bir sosyal temelin neredeyse tamamen yokluğu veya bunların toplum nezdinde birincil derecede önemli görülmemesi; yeni ilkelerin, kurumların, tekniklerin, uygulamaların ve kuralların topluma kitlesel ve katı bir şekilde 
sokulmasına sosyal sistemin hazırlıksızlı̆̆ı.

Anahtar kelimeler: Rusya tarihi, Pandemi/salgın, kolera, salgınla mücadele, karantina, sağlık, hijyen, sanitasyon.

$$
\text { 战的 }
$$

\section{ХОЛЕРА И ОБЩЕСТВО: ПРОТИВОЭПИДЕМИЧЕСКИЕ ПРАКТИКИ СТРАН ЗАПАДНОЙ ЕВРОПЫ, РОССИЙСКОЙ И ОСМАНСКОЙ ИМПЕРИИ В ХІХ - НАЧАЛЕ ХХ ВВ.}

\section{Аннотация}

Статья посвящена компаративному анализу сложения и динамике развития противоэпидемического реагирования государственных, научно-медицинских и общественных институтов крупнейших стран Западной Европы, а также Российской и Османской империй в течении пяти холерных пандемических волн, прокатывавшихся по населенным пунктам этих стран в XIX - начале XX вB. Различие уникальных особенностей социальной, культурной, политической жизни и вместе с тем, общая ориентация на один вектор развития делают анализ возможным и актуальным не только в общенаучном смысле, но и применимо к текущей противоэпидемической практике возникшей пандемии коронавируса (covid-19). Компаративное исследование построено на всестороннем анализе российской, американской, английской и турецкой историографии. В работе доказывается, что выработка противоэпидемической стратегии всегда является плодом уже сложившихся в обществе тенденций восприятия и реагирования на чрезвычайные и экстраординарные ситуации, форматов или паттернов «ответов» на глобальный «вызов», подвергающихся в процессе развития событий лишь определенной корректировке, добавлениям, обновлениям, частным инновациям и внедрениям. Огромную роль играет уверенность в выбранной стратегии или поиске стратегии, гармоничность выбранного пути или его поиска для общественных тенденций. Так, общая ситуация в странах Западной Европы с присущим им к началу XIX в. набором общественных признаков (секуляризм, лидирующая роль науки и ее саморазвивающийся потенциал, развитость общественной жизни и институтов гражданского общества) только подкрепляли выбранное направление поиска алгоритмов противоэпидемической политики, несмотря на нескорый результат, привели к позитивным сдвигам как в борьбе с холерой, так и развитии медицины в обществе в целом (система здравоохранения, социальная гигиена, санитария, профилактическая вакцинация и др.). Неровность в развитии этих общественных признаков при общей ориентации на схожий с Западной Европой путь поиска, непоследовательность взаимоотношений власти, медицины и общества в Российской империи не привели к началу ХХ в., несмотря на заметные успехи в тех или иных кластерах, к организации общей системы национального здравоохранения, являвшейся, при условии огромной территориальной протяженности страны, залогом эффективного внедрения противохолерных мер. Переход к европейским принципам противоэпидемического реагирования в жёстких условиях постоянного внешнеполитического прессинга, практически полное отсутствие социального фундамента для аккумуляции новаций, или его заведомая вторичность для общественных раскладов, неготовность общественной системы к массированному жесткому внедрению новых принципов, институтов, приемов, практик и правил в социум, как это произошло с Османской империей в XIX в., не способствовало, несмотря на создание практически всех звеньев и поддержания их работоспособности, сложению системы национального здравоохранения, способной выработать эффективную систему противоэпидемического реагирования в условиях османского социума.

Ключевые слова: История России, пандемия, холера, противоэпидемическое реагирование карантин, здравоохранение, гигиена, санитария. 


\section{Introduction}

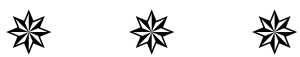

Since the end of the first quarter of the XIX century almost all countries are faced with persistent and periodically recurring epidemics on their territory. Waves of extreme cholera diseases, for centuries not only a test for the medical personnel of countries, the infectious problem that was directly related to the field of activity, but also for the society as a whole. An extraordinary autogenous disaster that befell countries in almost all corners of the world, seizing the settlements of entire continents, interrupting the steady course of their daily life, causing tremendous stress and panic in all layers, not only increased the requirements for its structures and the development of effective antiepidemic measures, new skills in sanitation and hygiene practices, but to the social interaction of society as a whole, which was the result of its action based on sanitary policy. It should not be forgotten that the unknown for the XIX - early XIX century the pandemic phenomenon coincided with industrialization process - unprecedented changes in the transport, communication, production, and urban life of society. Cholera went beyond a purely medical problem: according to F. Snowden, by the end of the 19th century it became the standard by which progress was measured and the government's desire to ensure the sanitary well-being of the population of countries was assessed. Adequate measures to prevent or counteract the spread of cholera disease contributed to the credit of public confidence in the existing state and social system as a whole, which, in turn, underlay the guarantee of its strength. The unique features of the countries of Europe, Russia, the Mediterranean and the Near East, their social, political, applied scientific and socio-cultural differences, but, at the same time, countries, in one way or another (where - by their natural development, where - by the will of a strategic or situational geopolitical the choice of elites) involved in the process of familiarizing with common formats and development schemes - European achievements, formats, patterns, makes this comparative study relevant and interesting. Moreover, at the beginning of the third decade of the XXI century the world community again faced a pandemic element, demonstrating in the new conditions a certain unpreparedness, and in some places ineffectiveness of the schemes tested by the past and, thus, again faces the need to develop or revise the foundations of an anti-epidemic strategy in new conditions or realities in accordance with their unique way development.

1) Countries of the European Community and the Fight Against Cholera in the 19th - Early 20th Centuries: Slow Positive Developments at a High Cost

After a period of revolutionary changes and the Napoleonic Wars of the late 18th early 19th centuries, the countries of Western Europe were in a situation of significant growth in public activity: the civil forces of these countries largely defended their right to special development from the monarchic regimes that recovered after these social cataclysms rather as a compromise in the situational alignment of new social and political forces. The absence of structural breakdowns associated with the complex of target inferiority and value identity, the almost secular attitude of European society towards religion and the almost privileged attitude towards science, as well as the separation of 
the economic and production spheres as a factor of independent socio-political properties with their interests determined the vectors of development of European countries in addressing new issues and challenges.

Initially, measures to stop the spread of cholera were based on the principles of combating the bubonic plague, however, since the appearance of cholera in Europe, the issue of infectiousness of the disease has become the subject of active discussions in the medical community between supporters and opponents of the idea of infectiousness (contagiousness) of the disease. These discussions were of great practical importance, since the anti-epidemic policy of individual states was built on the basis of the discussed concepts of the nature of the disease. Erwin Ackerknecht linked the adherence of countries to the concepts of contagionists, who believed that cholera spreads by contact, or anticontagionists (localists), who considered cholera physically non-infectious, but spreading through an unfavorable environment, with the political systems of these states. ${ }^{1}$ The peculiarities of the national-cultural power-administrative, medical, scientific, social dispositions provoked adherence to various directions in the tactics of anti-epidemic response. So, if in the first cholera epidemic of 1831-34 Britain and France abandoned large-scale quarantine and cordon measures, primarily focusing on the inviolability of freedom of trade, and completely relied on the actions of medicine and science to eliminate the situation, in Prussia and Austria-Hungary they perceived cholera as an invasion of enemy agents (infectious patients and their belongings), to combat which it was necessary to close the borders, restrict freedom of movement by quarantine measures. The damage caused by the introduction of quarantines to the economic life of countries, which, after the end of the first epidemic for the states, was larger than the human losses from cholera, subsequently contributed to their abandonment in Austria (1841) and Prussia (1847). ${ }^{2}$

Unavailability of a systemic response to the challenge of the second cholera pandemic in the late 1840s - early 1850s. after the failure of state measures in the early 1830s. provoked the authorities of most European countries, independently of each other, to practice a policy of hushing up the real scale of the epidemic, especially in those countries where there was an underdevelopment of public institutions or their great dependence on the state. ${ }^{3}$ This was greatly facilitated by the experience of understanding the role of the epidemic as a source of social tension (cholera unrest in Konigsberg, Stetten, Memel in Prussia; Exter, Glasgow, London, Liverpool in Britain, Paris and Lyon in France in 1831-32), repeatedly poured into urban unrest, undesirable in the already difficult social conditions in the second half of the 1840s. ${ }^{4}$ Nevertheless, in the first cholera epidemic, the minimum necessary infrastructure was created for carrying out anti-epidemic measures, which was subsequently expanded. This was facilitated by the development of railway communication and the media, which during the second

${ }^{1}$ E.H. Ackerknecht, "Anticontagionism between 1821 and 1867: The Fielding H. Garrison Lecture," International Journal of Epidemiology 38 (2009): 7-21.

2 Ackerknecht, "Anticontagionism between 1821 and 1867," 19; E. Visser Urban Developments in the Time of Cholera: Vienna 1830-1850 (Budapest: Master's dissertation, 2011), 42-44.

${ }^{3}$ R.J. Evans, "Epidemics and Revolutions: Cholera in Nineteenth-Century Europe," Past \& Present 120 (1988): 141.

${ }^{4}$ Evans, "Epidemics and Revolutions," 131-132, 138. 
pandemic significantly accelerated the information and arrival of medical personnel to the site for anti-cholera measures.

The search for a solution to problems with a scientific and medical approach in Western Europe proceeded from a public understanding of the role of a particular branch of science, medicine, engineering practice, state and public participation in the development of the country in general. So, the primary interest of the English society of the XIX century. to the introduction of technical innovations in the economic and social sphere, along with the emphasized democracy of internal public relations and the advantages in solving internal issues of local government, contributed to a significant reorganization of the sanitary infrastructure of British cities in the 1850s and 60s, which led to the localization of cholera manifestations from the second half $1860 \mathrm{~s}$ In addition, the endowment of sanitary medicine with administrative functions (institute of sanitary inspection, since 1846) and professional and public control over the quality of antiepidemic measures by independent structures of civil society (Association for the improvement of cities, 1844; for cleaning rivers, 1872; combating smoke, 1882) contributed to the addition of the national health care system by the early 1870s. 5 Nevertheless, according to some researchers, the British sanitary experience was unique and was a consequence of the formation in the country for that time of rare economic conditions that could not be easily replicated and copied by other countries. With longterm loans, Victorian cities spent $\$ 100$ million on sanitation in one decade, which could not be expected from cities in other countries due to the specifics of their economic development. 6

The surge in the development of national science in Germany, by the middle of the 19th century proved its decisive role for the economic and state development of the German lands in the context of their national tasks with limited material resources, determined the vector of the German anti-epidemic response. After some failure in the administrative and police implementation of choleratic measures in the first pandemic, it starts from strict scientism with a focus on innovative approaches of an experimental nature in medical science, which, however, did not bring an immediate effect in preventing epidemics. Great influence in the 1850s - mid 1880s had the activity of the Bavarian hygienist, professor of medicine at the University of Munich M. von Pettenkofer (1818-1901), who, having substantiated the economic efficiency of preventive measures to the municipal authorities, opposed other state intervention in the fight against the epidemic, including the isolation of cholera sick.7 Despite the fact that M. Pettenkofer's epidemiological ideas became widespread both in Germany and in other European countries and for several decades formed the basis of algorithms for combating cholera epidemics, contributing to the improvement of the urban environment, the widespread

${ }^{5}$ P.G. Paterson "The Health of Towns Association in Great Britain 1844-1849: An Exposition of the Primary Voluntary Health Society in the Anglo-Saxon Public Health Movement," Bulletin of the History of Medicine 22/4 (1948): 373-374; D. Gladstone and S.E. Finer, Edwin Chadwick: Nineteenth-century Social Reform (London: Routledge, 1997), 348.

${ }^{6}$ C. Hamlin, Cholera: The Biography (Oxford: Oxford University Press, 2009), 139-140.

${ }^{7}$ R. Evans, Death in Hamburg: Society and Politics in the Cholera Years, 1830-1910 (New-York: Penguin Books, 2005), $242-243$ 
dissemination of social hygiene and sanitation, ${ }^{8}$ a cardinal fracture in the fight against cholera in Germany, new discoveries in another branch of German scientific and medical knowledge contributed - microbiology, produced by an employee of the imperial health administration, professor of the Berlin Institute of Hygiene R. Koch (1843-1910) in 1883, who identified the bacterial pathogen of cholera. After R. Koch singled out Vibrio cholerae, which actually crossed out the anti-contagious theory of M. von Pettenkofer, "European governments, relying on past administrative experience, but acting in accordance with medical instructions, organized massive preventive campaigns for quarantine, disinfection and isolation of victims", tested during the Hamburg cholera epidemic of 1892. Combining the achievements of two branches of the German epidemiological school, different in their approaches, by the beginning of the XX century. contributed to the development of a universal effective strategy for combating and preventing cholera (rapid elimination of the outbreak in Berlin, 1905). ${ }^{9}$

Nevertheless, despite the positive shifts in the study of the nature of the development of the disease and its symptoms, the formation of the health care system and medical response, the basic principles of public hygiene and sanitation, as well as the widespread use of sanitary policy at the state level in European countries by the beginning of the 20th century, the development of universal methods of counteraction and prevention of cholera occurred relatively slowly with the continuing significant mortality of the population during epidemic waves. Only the accompanying factors in the development of the social, political and economic life of society made this problem less urgent for society, and, at the same time, contributed to the understanding of the scientist way of fighting cholera exclusively in a positivist way.

2) The Russian State and Society in the Fight Against Cholera in the 19th Early 20th Centuries: Internal Inconsistency and Running on the Spot

The arrival of the cholera pandemic in the Russian Empire in the early 1830s. fell on the period of the birth of the national medical school. Until that moment, the state, which set the initiative in the overall development of the country, focused on the formation of medicine mainly to meet the needs of the military sphere, where there was some consistency in organizing its affairs, while the largest civilian hospitals were created mainly on the initiative of individuals and estate-corporate charitable organizations, and medical science was characterized by a shortage of qualified Russian specialists and a strong dependence on foreign specialists. These circumstances led to the dependence of the medical profession on the authorities, with a practical absence of independent initiatives. ${ }^{10}$ With the appearance of cholera within Russia, this led to an orientation towards the state, administrative and police anti-epidemic response, based, as in the case of the plague, on the widespread use of quarantine-cordon measures, however, which did not bring a tangible effect in slowing down and localizing the spread of the disease in the country. Mainly, it contributed to an increase in social tension in the country's cities

\footnotetext{
${ }^{8}$ A. Morabia, "Epidemiologic Interactions, Complexity, and the Lonesome Death of Max von Pettenkofer," American Journal of Epidemiology 166/11 (2007): 1234.

${ }^{9}$ Evans, "Epidemics and Revolutions," 144.

10 Ya. Chistovich, Istoriya pervykh meditsinskikh shkol v Rossii (Moskva: Kniga po trebovaniyu, 2013 ), 106.
} 
(street riots - "cholera riots" in the cities of Sevastopol, Tambov, St. Petersburg, Staraya Russa, 1830-1832), which expressed itself, as in Europe, in the form of protests against foreign doctors. ${ }^{11}$ Nevertheless, young cadres - graduates of medical schools, as well as private benefactors who actively participated in the implementation of volunteer assistance or financed the opening of hospitals and infectious diseases hospitals - showed themselves very heroically. ${ }^{12}$ Aware of the general harm from the application of broad quarantine restrictions in the first cholera epidemic, the Russian authorities subsequently did not widely practice such a strategy. Strengthened administrative supervision over internal relationships in the corporation, increased regulation of production processes provokes in it the development of methods of informal self-organization for the study of cholera symptoms that existed in Russia before the broad social reforms of the 18601870s. ("Pirogov's circle" of the late 1840s). In addition, the geographical and class imbalance in the spread of health care standards in the country was a significant inhibiting factor.

A sharp change in the political vector in Russia from a rigid administrativebureaucratic, repressive-prohibitive to liberal in all respects and directions of public life gave a huge impetus to the development of medicine, both in the scientific, medicalapplied and public-civil sense. This set a solid foundation for the formation of the national school of infectious diseases (S.P. Botkin), sanitation and hygiene (A.P. Dobroslavin, F.F. Erisman), experimental medicine (N.F. Gamaleya, D.K. Zabolotny) , the formation of public organizations of medical personnel (Russian Epidemiological Society, 1865; Society of Russian doctors named after N.I. Pirogov, 1881; cholera congresses of doctors in 1892, 1898). Another undoubted achievement of the Russian national medical school was the formation of a network of zemstvo, ambivalent municipal medical services, in the European provinces of the Russian Empire, which became the most territorially largescale at that time in the world. ${ }^{13}$ The intensification of the introduction of medical practices, which coincided with some shifts in the improvement of the urban environment in the 1860s-80s. contributed to a certain success of anti-epidemic actions during this period, which somewhat reduced overall mortality during urban cholera outbreaks of the 1860s-70s. ${ }^{14}$

On the other hand, the dizziness of success among the medical community from the significant extensive growth of its scientific and social potential combined with practical application during this period, as well as the objective limited reserves of public resources for its full-scale implementation, made it impossible for further development without active government assistance, which claimed, at the same time and on the leading

${ }^{11}$ K.G. Vasil'yev i A.Ye. Segal, Istoriya epidemiy v Rossii (Materialy i ocherki) (Moskva: Medgiz 1960), 256-257; K.S. Barabanova, "Pervaya kholera v Sankt-Peterburge v 1831 g.: protivoepidemicheskiye meropriyatiya," Trudy Instituta rossiyskoy istorii 12 (2014): 140.

12 R.E. McGrew, Russia and the Cholera, 1823-1832 (Madison, University of Wisconsin Press, 1965 ), 76.

13 M.V. Poddubnyy i I.V. Yegorysheva, Istoriya zdravookhraneniya dorevolyutsionnoy Rossii (konets XVI - nachalo XX vv.) (Moskva: «GOETAR-MEDIA» 2014), 176-180; L.N. Karpov, Zemskaya sanitarnaya organizatsiya v Rossii (Leningrad: «Meditsina», 1964).

${ }^{14}$ G.I. Arkhangel'skiy, Kholera v Peterburge v prezhniye gody (SPb., Tip.-lit. Shredera, 1892), 11-14. 
organizing role of the Russian health care system. ${ }^{15}$

In the context of the administrative-bureaucratic model of a state of considerable size, the state resource in the fight against cholera was more ambitious than the public one, but less structured, less flexible and ideologically uncompromising. In addition, the active involvement of the state resource was motivated by the need to increase the territorial coverage of the medical network. At the same time, the expansion of this network also required an increase in the medical staff in different regions of Russia, which made a huge demand for qualified human resources, but at the same time, due to the difficult socio-political development of the country, made the process of its formation dependent on the practiced informal and even oppositional social projects practiced by educated communities (leftist zemstvo liberalism, narodnichestvo, and later, socialism). ${ }^{16}$ All this led to the development of an anti-epidemic response in Russia to an organizational impasse and structural imbalance: a fully capable (from the point of view of the European scientific and medical school and practice) and developed national medicine was not able to convert its achievements on a large-scale into anti-epidemic practice throughout the country due to a conflict relationship with the owner of resources, the state. The still difficult epidemic situation in the country with an increase in mortality during new cholera outbreaks of the late 19th - early 20th centuries. (1892-93, 1898 and 1907-11), marked very small shifts that have been achieved by Russian healthcare, which has gone through a huge path of internal development over a century.

\section{3) The Fight Against Cholera in the Ottoman Empire and in the 19th - Early 20th Centuries: Foreign Pressure and Local Problems}

The emergence of a cholera epidemic in the Ottoman Empire in the early 1830s. coincided with a very difficult external and internal political situation in which this state found itself. The development of shipping in the Mediterranean basin by European countries in the second half of the 18th - early 19th centuries, psychological complexes of geopolitical inadequacy that emerged in the ruling elite of the Ottoman state due to a protracted series of military defeats from European countries (Austria, Russia, France) at this time, regional separatism in Rumelia (Balkans) and Egypt, coupled with the socioeconomic pressure of European countries, determined the development of anti-epidemic response tactics. Despite some shifts in the scientific understanding of the nature of the development of epidemics among Ottoman intellectuals at the beginning of the 19th century. (Hamdan bin Osman, contagiousness of diseases), and, accordingly, their thoughts on the adequacy of quarantine measures widely practiced in the West to Muslim law, the general underdevelopment of medical science and practice, and, conversely, the existence of a traditional religious and mystical that was not crisis-free until that moment, Fatalistic attitudes towards deadly diseases and epidemics in the bowels of the basically Muslim Ottoman society make a radical change in response extremely difficult to

\footnotetext{
15 I.A. Tarasova, “Deyatel'nost' Ministerstva vnutrennikh del Rossiyskoy imperii po sozdaniyu sistemy nadzora i kontrolya za sanitarno-epizooticheskoy obstanovkoy vo vtoroy polovine XIX veka," "Chernyye dyry» v rossiyskom zakonodatel'stve 4 (2012): 11.

${ }^{16}$ N.M. Pirumova, Zemskaya intelligentsiya i yeye rol'v obshchestvennoy bor'be do nachala XX v. (M.: Nauka, 1986)
} 
implement. ${ }^{17}$

The first set of measures of the state anti-epidemic response were port quarantine bans, organized under pressure from European countries by Sultan Mahmud II and his chief physician Behcet Effendi for arriving ships in Istanbul during the cholera epidemic that broke out in 1831. ${ }^{18}$ Despite the confirming fatwa of Sheikh-ul-Islam, the innovation is not typical for the everyday life of Muslim society, to the execution of which European medical specialists were involved, caused social discontent, which turned into pogroms of quarantine institutions, reprisals against European doctors (Izmir, 1832; Amasya, 1840). ${ }^{19}$ Extremely forced, and somewhere pressured reforms on the installation of services and administrations of the medical, quarantine and sanitary sphere, the early creation of medical educational institutions based on European types, carried out in the period preceding the Tanzimat reforms at the first stage of its implementation (18201840s), in many ways did not have time to bear fruit in the face of a rapid geopolitical and pandemic onslaught on the country. It only strengthening the influence of foreign European experts in the development of anti-epidemic measures of the state, which, in addition to being political, was in a tough cultural and mental confrontation with Western countries. $^{20}$ The wide reforms in all spheres according to Western types put the independent formation of principles and concepts for understanding the symptoms of cholera disease, based on the experience of the development of Ottoman medicine at that time, on the marginal border of the scientific and medical discourse in the country (treatises on Hamdan's cholera -bin-Osman, 1831; Ismail-pasha, 1847), ${ }^{21}$ open for study only to a narrow group of Ottoman intellectuals, brought up in the high traditions of Arab literacy.

Since the end of the 1840s. the epidemic situation in one of the regions of the Ottoman Empire - the Hejaz, the coast of the Red Sea of the Arabian Peninsula, a place, where huge masses of Muslim pilgrims circulate, contributing to the rapid spread of cholera throughout the Mediterranean, from which it is one of the main sources of cholera entering Europe and America became an international problem. ${ }^{22}$

A situation that was really less-controlled by the Ottoman authorities in the period 1830-60s. in view of the special sacred position of the region for all Muslims of the world, as well as other, more significant state problems. All this leads to constant claims of the European side against the Ottoman government, formalized in the form of international sanitary meetings and conferences in 1850-90, expressed in constant demands for tougher transport quarantines, improved supervision and control, as well as the quality of service in observators and hospitals. Requirements from the Ottoman authorities to

17 B. Bilmus, Plague, Quarantines and Geopolitics in the Ottoman Empire (Edinburgh, Edinburgh University Press, 2012), 123.

18 Bilmus, Plague, Quarantines and Geopolitics, 125.

19 Bilmus, Plague, Quarantines and Geopolitics, 130-131.

${ }^{20}$ Bedi N. Şehsuvaroğlu, Türkiye Karantina Tarihine Giriș [Introduction to the History of the Quarantine in Turkey, Introduction a l'histoire de la quarantaine en Turquie] (İstanbul: Ismail Akgun Matbaasi, 1959), 326-27; A. Erdemir ve I. Kahya, Bilimsel Çalışmalar Işı̆̆ında Osmanlıdan Cumhuriyete Tıp ve Sağlık Kurumları (Ankara: Türkiye Diyanet Vakfı Yayınları), 2000.

${ }^{21}$ R. Politzer, Cholera. World's Health Organization (Geneva. WHO Publishers, 1959), 32,36.

22 Politzer, Cholera, 40. 
carry out a strict quarantine policy in the region is imposed on circumvention of its implementation by European trade and transport agents (primarily shipping companies that claimed to monopolize the sea transport of Muslim pilgrims), due to the existence of trade surrenders. Some attempts by Sultan Abdul-Hamid II to enforce quarantine rules on foreign companies and their representations in the ports of the empire in 1879 and 1893 were not crowned with success. Despite the fact that internationally raised questions about the sanitary state of the Hejaz provoke the Ottoman authorities to tackle this issue tightly, sending there inspections and medical missions $(1866,1867,1871,1879,1881$, 1893), erecting and updating quarantine points and infectious diseases hospitals , carrying out sewage disposal and disinfection in the ports of the region and even in Mecca itself (1894), all this largely led to the dispersion of the few state resources and the weakening of the Ottoman positions in the territories cut off from the center through provocation for spending and the exact execution of the rules by the Ottoman authorities and subjects themselves. ${ }^{23}$

During the XIX - early XX century all links for the health sector were founded in the Ottoman Empire: management, medical education in 1820s-1840s. with their further updating in the 1880s, ${ }^{24}$ modern scientific laboratories and research institutes in $1893 ; 25$ scientific and medical public organizations (set in 1850s-70s) and professional associations of doctors (1900s). It also created the founder of sanitary infrastructure in big cities (Istanbul, Izmir, Thessaloniki) also disinfection and sewage practices by sample of Europe were mastered and tested, and attempts were made to establish interaction between these health structures (cholera epidemic in Istanbul, 1893). ${ }^{26}$ However, despite all this, their overall capacity to deal with epidemic issues remained very weak. A very complicated, multi-level state organism of interethnic and interregional relations of the Ottoman Empire, combining various cultural and mental characteristics of the Islamic and Christian, Mediterranean, Arab and Turkic-Asian-nomadic worlds, limitedly subject to the processes of interpenetration and exchange, turned out to be extremely insensitive to large-scale and forced innovations of the Western type, undertaken under acute pressure of external and internal circumstances. Thus, to put together the educated links of the medical sphere, carved according to European models and in many respects by them and provided with the sanction of the highest power in the interconnected sphere of public health care for the Ottoman leadership by the beginning of the 20th century. failed. The situation when the Ottoman court successfully performed only transactional and coordinating actions between different, semi-isolated from each other and closed in their

${ }^{23}$ M. Harrison, “Quarantine, Pilgrimage, and Colonial Trade: India 1866-1900," The Indian Economic and Social History Review 29/2 (1992), 124-25; G. Sariyildiz and O. Daglar Macar, "Cholera, Pilgrimage and international politics of sanitation: the quarantine station of Kamara," Plague and contagion in the Islamic Mediterranean, ed. Nükhet Varlik, (Amsterdam: ARC Amsterdam University Press, 2017), 260-261.

${ }^{24}$ N. Yıldırım, “Tanzimat'tan Cumhuriyet'e Koruyucu Sağlı Uygulamaları," Tanzimat'tan Cumhuriyet'e Türkiye Ansiklopedisi 5, ed. M. Belge (Ankara: İletişim Yayınları, 1985), 1325.

${ }^{25}$ H. Ertin and N.Yıldırım, "European Experts in the Istanbul Cholera Outbreak in 1893-1895 and Their Contribution to Health Modernization in the Ottoman State," Anadolu Kliniği Tıp Bilimleri Dergisi 25/1 (2020): 86, 92-93.

${ }^{26}$ A.D. Moulin, "Nachalo globalizatsii zdravookhraneniya vo vremya Krymskoy voyny (1853-1856) i proyekty sanitarnykh reform v Osmanskoy imperii," Istoriya meditsiny 1 (2014): 61-77; E. M. Atabek, 1851'de Paris'te toplanan I. Uluslar arası Sağlık Konferansı ve Türkler [The First International Sanitary Conference that met in Paris in 1851 and the Turks] (İstanbul: İstanbul University Cerrahpaşa School of Medicine Publications, 1974), 49. 
inner life ethno-confessional substrates that made up the body of the empire, was replaced by the need for full-scale introduction of new and identical sanitary subjects into their life, hygienic, medical rules, practices, patterns, but at the same time, culturally and mentally not close to them and not familiar. The introduction of Western typed medicine, in addition to foreign specialists, gave advantages to non-Muslim subjects of the empire, which, quite naturally, caused distrust on the part of more numerous segments of the population, calling the implementation of the health policy of the authorities "capitulations of health care". As a result, the state medicine and sanitation failed to develop a general strategy for responding to cholera pandemics, the pandemic continued to depend on the country's medical sector on the prescriptions of foreign specialists, the credit of which, due to the cultural and mental characteristics and the closed residence of communities in the empire, continued be significant.

\section{Conclusion}

Falling on the countries of Europe, Russia and the Middle East since the 1830s. an extraordinary deadly pandemic disaster of a new type, the peculiarities of its spread, the enormous threats of mortality among the sick, etc. caused the need for a significant revision of the foundations of administrative and medical policy in these countries. It should be noted that all countries, without exception, were not ready to confront the cholera epidemic, so there is no need to talk about the pronounced advantages and direct disadvantages of one or another anti-epidemic response path. In all cases, the shifts were achieved over a long period of time - from 40 to 80 years, accompanied by periodically rolling waves of disease with significant human mortality. The decisive factor in this regard was the addition of the formats of countering the epidemic with the connection to it of state, public, intellectual, information resources. So, after the end of the first cholera pandemic in European countries, a progressive trend for the formation of an anti-cholera response was clearly defined - a scientific and medical one, which took the palm from the hands of the administrative one, which clearly showed its ineffectiveness both in antiepidemic and general economic terms. Despite the fact that, unlike the second, the former was in no hurry to offer universal recipes, striving, as far as conditions allow, to fully and comprehensively study the problem, the connectivity of scientific associations with other structures of civil society developed in Europe helped to protect them from the encroachments of the authorities, who are certainly interested in the early development and implementation of anti-epidemic algorithms in the life of the country. The development of the medical service, its close intertwining with administrative and technical functions and profiles, as a result - by the 1870s. gave the countries of Western Europe integral public health systems that very quickly accumulated new scientific discoveries, transposing and adapting their achievements for the entire population.

On the contrary, the inconsistency of the course of the authorities in relation to the medical sphere, characterized by sudden extreme tightening and warming, as was the case in the Russian Empire, ultimately contributed to the development of medicine on an alternative to the state, on social grounds and resources. Certain extensive successes of Russian medicine observed on the anti-epidemic front in the 1860s and 80s, although not 
directly, but financed at the state expense, caused an overestimation of its real capabilities, the absolutization of relative successes. The need for the participation of the state resource in the formation and organization of the sphere of national health care raised legitimate questions among representatives of public medicine. The protracted confrontation between the authorities and the medical community of Russia on the issue of supremacy in the future system of national health care at the beginning of the 20th century is accompanied by new, no less deadly than the first, cholera pandemics, which only radicalized the existing contradictions.

The absence of any European-wise, medical sphere in the Ottoman Empire, and at the same time, the use of the epidemic situation as one of the levers of foreign policy pressure from European countries on the Porto, provoked the Ottoman authorities to start introducing quarantine measures, to carry out forced reforms in the healthcare sector, medical services, institutions of sanitary policy in the country. At the same time, the specificity of interethnic interaction, which was firmly established in the Ottoman Empire earlier, contributed to the rooting in the popular mass of prescientific, creationist views on the nature of the spread of deadly diseases. The period of transition to massive and large-scale reforms in various spheres of the life of the state and society relied only on the Ottoman top administrative apparatus, which is few in number and does not rely on the local authorities dependent on it, prepared exclusively for carrying out the functions of point transactions between various ethno-confessional blocks of the empire, and not to actions of speedy massive introduction of new incomprehensible schemes into the consciousness and practice of social everyday life. The physical unpreparedness of the corps of its own medical personnel in the context of the ongoing cholera epidemics and foreign policy pressure forced them to increasingly resort to the help of foreign doctors and hygienists. The massive admission of foreign European specialists to the ports and settlements of the Ottoman Empire for medical and sanitary measures, which had been part of the system for a century, did not contribute to the creation of the foundation of the national medical school and public health, but only provoked a constant increase in tension among the country's population.

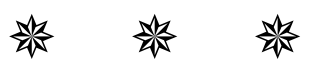

\section{Katkı Oranı ve Çıkar Çatışması Beyanı (Zorunlu)}

Tek yazarlı makaledir. Katkı payı \%100 yazara aittir. Çıkar çatılması yoktur.

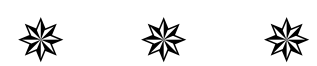

\section{REFERENCES}

Ackerknecht, E.H. "Anticontagionism between 1821 and 1867: The Fielding H. Garrison Lecture." International Journal of Epidemiology 38 (2009): 7-21.

Arkhangel'skiy, G.I. Kholera v Peterburge v prezhniye gody. SPb.: Tip.-lit. Shredera, 1892. 
Atabek, E. M. 1851'de Paris'te toplanan I. Uluslar arası Sa ğlık Konferansı ve Türkler [The First International Sanitary Conference that met in Paris in 1851 and the Turks]. İstanbul: İstanbul University Cerrahpaşa School of Medicine Publications, 1974.

Barabanova, K.S. "Pervaya kholera v Sankt-Peterburge v 1831 g.: protivoepidemicheskiye meropriyatiya." Trudy Instituta rossiyskoy istorii 12 (2014): 129-143.

Bilmus, B. Plague. Quarantines and Geopolitics in the Ottoman Empire. Edinburgh: Edinburgh University Press, 2012.

Chistovich, Y.A. Istoriya pervykh meditsinskikh shkol $v$ Rossii. Moskva: Kniga po trebovaniyu, 2013.

Gladstone, D., Finer S.E. Edwin Chadwick: Nineteenth-century Social Reform. London: Routledge, 1997.

Erdemir, A., Kahya I. Bilimsel Çalışmalar Işı̆̆ında Osmanlıdan Cumhuriyete Tıp ve Sağlık Kurumları Ankara: Türkiye Diyanet Vakfı Yayınları, 2000.

Ertin H., Yıldırım N. "European Experts in the Istanbul Cholera Outbreak in 18931895 and Their Contribution to Health Modernization in the Ottoman State." Anadolu Kliniği Tıp Bilimleri Dergisi 25 (Supplement 1) (March 2020): 85-101.

Evans, R.J. "Epidemics and Revolutions: Cholera in Nineteenth-Century Europe." Past \& Present 120 (1988): 123-146.

Evans, R. Death in Hamburg: Society and Politics in the Cholera Years, 1830-1910. NewYork: Penguin Books, 2005.

Hamlin, C. Cholera: The Biography. Oxford: Oxford University Press, 2009.

Harrison, M. “Quarantine, Pilgrimage and Colonial Trade: India 1866-1900.” The Indian Economic and Social History Review 29/2 (1992): 117-144.

Karpov, L.N. Zemskaya sanitarnaya organizatsiya v Rossii. Leningrad: Meditsina, 1964.

McGrew, R.E. Russia and the Cholera, 1823-1832. Madison: University of Wisconsin Press, 1965.

Morabia, A. "Epidemiologic Interactions, Complexity, and the Lonesome Death of Max von Pettenkofer." American Journal of Epidemiology 166/11 (2007): 1233-1238.

Moulin, A.D. "Nachalo globalizatsii zdravookhraneniya vo vremya Krymskoy voyny (1853-1856) i proyekty sanitarnykh reform v Osmanskoy imperii." Istoriya meditsiny 1 (2014): 61-77.

Snowden, F.M. Naples in the Time of Cholera, 1884-1911. Cambridge: Cambridge University Press, 2002.

Paterson P.G. “The Health of Towns Association In Great Britain 1844-1849: An Exposition of the Primary Voluntary Health Society in the Anglo-Saxon Public Health Movement." Bulletin of the History of Medicine 22/4 (1948): 373-402. 
Pirumova, N.M. Zemskaya intelligentsiya i yeye rol' $v$ obshchestvennoy bor'be do nachala XX v. M.: Nauka, 1986.

Poddubnyy, M.V., Yegorysheva I.V. Istoriya zdravookhraneniya dorevolyutsionnoy Rossii (konets XVI - nachalo XX vv.). Moskva: «GOETAR-MEDIA» 2014.

Politzer R. Cholera. World's Health Organization. Geneva: WHO Publishers, 1959.

Sariyildiz G. and O. Daglar Macar, "Cholera, Pilgrimage and international politics of sanitation: the quarantine station of Kamara." Plague and contagion in the Islamic Mediterranean. Ed. Nükhet Varlik. Amsterdam: ARC Amsterdam University Press, 2017, 243-307.

Şehsuvaroğlu, Bedi N. Türkiye Karantina Tarihine Giriş [Introduction to the History of the Quarantine in Turkey, Introduction a l'histoire de la quarantaine en Turquie]. İstanbul: Ismail Akgun Matbaasi, 1959.

Tarasova, I.A. “Deyatel'nost' Ministerstva vnutrennikh del Rossiyskoy imperii po sozdaniyu sistemy nadzora i kontrolya za sanitarno-epizooticheskoy obstanovkoy vo vtoroy polovine KHIKH veka." «Chernyye dyry» v rossiyskom zakonodatel'stve 4 (2012): 9-12.

Vasil'yev, K.G., Segal, A.Ye. Istoriya epidemiy v Rossii (Materialy i ocherki). Moskva: Medgiz, 1960.

Visser, E. Urban Developments in the Time of Cholera: Vienna 1830-1850. Budapest: Master's dissertation, 2011.

Yıldırım, N. “Tanzimat'tan Cumhuriyet'e Koruyucu Sağlık Uygulamaları." Tanzimat'tan Cumhuriyet'e Türkiye Ansiklopedisi 5. ed. M. Belge. Ankara: İletişim Yayınları, 1985.

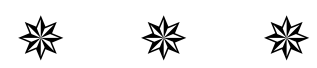

